\title{
The Principle Of Good Faith In Civil Law
}

\author{
Mahsuda Tadjibayeva Rustamjonovna \\ Lecturer, Department of Business Law, Tashkent State University of Law, Tashkent, Uzbekistan. \\ E-mail: mtadjibayeva@gmail.com
}

Article History:Received:11 January 2021; Accepted: 27 February 2021; Published online: 5 April 2021

\begin{abstract}
The article explores the essence of the principle of good faith in modern civil law, the doctrines in which this principle is reflected, the functions of the principle of good faith in civil law, the need for the concept of good faith in civil law and problems in the application of this principle in the Civil Code. To this end, the author discusses not only the expression of this principle in doctrines, but also the extent to which it has been studied in civil law in foreign countries, and the expression of the principle of good faith in the current Civil Code and the draft of the new Civil Code of Uzbekistan.

In addition, a number of civil law relationships that have not been sufficiently explored have been studied, requiring the systematization of knowledge due to the different manifestations of the category of integrity, as well as the practical significance of this category in civil law relations. In this regard, this article

highlights the shortcomings of the principle of good faith in the current Civil Code of the Republic of Uzbekistan.
\end{abstract}

Key words: good faith; conscientiousness; civil law principle; justice; rationality; civil code; diligent purchaser; possession; property.

\section{Introduction}

From Roman law to modern law, the principle of good faith or fairness, which is the essence of the law, has not changed itself. The question of whether a participant in civil proceedings should act in good faith, take into account the interests of the other party within the relationship, or whether he can put his own interests first even if he harms his partner, is answered by modern Roman law with an effective civil law relationship based on a partnership for a purpose rather than a combative action [13]. This means acting conscientiously and appropriately, taking into account the expectations of the other party in the relationship through the principle of good faith. In this regard, this principle is one of the most important categories in most civil law systems.

The civil law of many countries provides for the principle of fairness in entering into civil law relations, in particular in negotiations, use their rights, performance of obligations, interpretation of the contract and other cases. However, the scope and level of honesty are radically different in different legislative systems. Similarly, the concept of fairness is not the same in every countrys' legal system. For example, the interpretation of the concept of good faith in Spain law differs from the interpretation in French law. This article considers that the most important principle in the regulation of relations between subjects of civil law is honesty, to study its essence and its expression in doctrines, first of all, to study its expression in doctrines, civil codes of foreign countries and the current Civil Code of the Republic of Uzbekistan. The new Civil Code aims to study the expression of the principle of fairness in the draft. At the end of the article, the author highlights the shortcomings of the principle of fairness in the current Civil Code of the Republic of Uzbekistan.

\section{How is the principle of good faith reflected in the civil codes of foreign countries?}

Good faith is a key principle in modern legal systems, in common law as well as in civil law [1]. Of particular importance is the condition of the application of the principle of good faith in the following civil legal relations of these legal systems. In particular, the principle of good faith was the main criterion for the obligation to negotiate in good faith, trust and confidentiality in contract negotiations, the obligation of fidelity in contract performance, the obligation to give notice before and during the term of the contract, the obligation to cooperate with his contractor to ensure the satisfactory performance of the contract.

In Germany, the principle of good faith initially applied only to the performance of an obligation, but in the process of applying the law the Germans were forced to apply this principle in all areas of social relations (corporate law, family law, etc.)[2].

By the end of the twentieth century, the concept of good faith, referred to in certain situations in the civil codes of most foreign countries, rose to the level of general principles of civil law[3]. In particular, while the Napoleonic Code of 1827 (or the French Code) provides that the fulfillment of obligations is based on the principle of good faith, the German Civil Code also makes the principle of good faith one of the basic principles governing civil relations. In this case, based on the principle of good faith, it serves as a basis not only for the fulfillment of an obligation, but also for the obligation to compensate for damages. This also manifests itself as a basic principle of contract interpretation. 
The Italian Civil Code, like the aforementioned Codes, states that the principle of good faith must be strictly observed in the fulfillment of obligations, in the fulfillment of contract terms and in the interpretation of the contract, as well as in negotiations.

In Switzerland, the principle of good faith is a general principle of the Civil Code and therefore applies to all civil law institutions. Article 2 of the Civil Code establishes the general principle of civil law according to which everyone must exercise his or her rights and act in good faith in the performance of his or her obligations.

This is repeated in the Civil Code of the Russian Federation. In particular, Article 1 of the Code states that "participants in civil legal relations shall act in good faith in establishing, exercising and protecting civil rights and fulfilling civil obligations. In connection with the reform of Russian law in recent years, Article 10 of the Code prohibits the exercise of one's rights with the intention to cause harm to another person, unlawful acts, as well as other intentional bad faith exercise (abuse of rights) of civil rights. Since 2015, Article 307(3) of the Civil Code obliges the parties to act in good faith in establishing, performing and terminating obligations. The parties must act in good faith, taking into account each other's rights and legitimate interests, in establishing, performing and terminating obligations, and amendments have been made to oblige them to provide each other with the assistance and information necessary to achieve the purpose of the agreement [2].

In the Dutch Civil Code, the principle of good faith underlies not only the performance of an obligation and the rules of a contract, but also the rights and obligations of a legal entity [3].

The category of good faith also appears in several contexts in the Colombian Civil Code. In particular, a good faith owner who must return an item to its rightful owner is entitled to be reimbursed for necessary and useful expenses incurred in connection with it; a good faith purchaser of stolen chattels enjoys protection if they were purchased from the seller in retail outlets or open markets; a payment made in good faith to a particular creditor is considered real, even if someone else later turns out to be the real creditor. [5]

In the last decades of the twentieth century, French courts and doctrines began to interpret the principle of good faith broadly, drawing on global trends [3]. The interpretation of the rule of good faith performance as a general principle of civil law defines a number of institutions, and this is evident in the mastery of German jurisprudence and legal practice. Today this principle is embraced by supranational European instruments claiming to unify contract law or even all private law [3].

\section{What is the essence of the principle of good faith in civil law? Which doctrines reflect this principle?}

It is very difficult to describe what the concept of good faith means in one or even a few short sentences, because it is a very flexible concept, if reinforced as a legal principle, will become a 'rubber-stamp' norm [3]. In the German literature, good faith is recognised as a criterion before the law. It is recognised that the existence of a legal system is absolutely impossible without the principle of good faith, it is the synthesis of ethics and morality in the rule of law [2].

According to the doctrine, the concept of good faith can be divided into a subjective and an objective one. Whereas the concept of good faith in the subjective sense consists of the formula 'did not know and should not have known', in the objective sense the concept of good faith is a requirement for correct conduct in the law of obligation [2] . Above all, the principle of good faith in the subjective sense is that people are sufficiently unaware of the negative consequences of the legal situation and the shortcomings of certain property rights [5].

Pre-revolutionary French law held that good faith required "the agreement of the parties to be genuine and the parties to refrain from fraud, violence, any dishonesty or fraud"; it also stipulated that a contract based on good faith must be reliable and reasonable. Finally, the contract states that it must not be contrary to divine law, good morals and "general profit" [5].

Nowadays, good faith in contract law has a narrow meaning ("objective good faith"). To understand this meaning, legal doctrines use the following terms: "fairness, good faith behaviour, reasonable standards of good faith, morality, rationality, social ethics, spirit of solidarity, standards of social justice" and "true honesty", an objective standard based on the rules of ethics, commercial or otherwise, justice or reasonableness of society [4].

The doctrine of contractual liability of the German jurist Rudolf von Iering directly addresses the category of good faith and so the rule of good faith came to be applied together with a special rule of liability for information on the essential terms of the contract [3]. (e.g. to provide information about neighbours before entering into a lease).

In the Italian Civil Code of 1942, two norms have always accompanied each other: while the first norm required that negotiations be based on a standard of good faith (Article 1337), the second norm established that the party who concealed information that led to the invalidity of the contract must compensate the injured party for its costs (Article 1338). The counterparty's commitment to the principle of good faith is so important that not only the facts directly related to the contract but also all other facts partly related to the contract make sense.

Doctrine and jurisprudence have expanded the obligations of parties to exchange information outside of the contract. These changes have led to the fact that bad faith behaviour when entering into a contract can be grounds for subsequent termination [3]. 
Examples include the following rules, where we can witness the strengthening of the Anglo-Saxon legal system through civil law provisions showing the principle of good faith in European civil law: the institution of "culpa in contrahendo" in modern law, including liability for the actions of workers before the conclusion of a contract; the system of additional obligations (Nebenpflichten), accompanying the main obligations: the obligation to take into account the interests of the other party (duty of loyalty), including the requirement to prevent the repayment of debt in kind, which may be too burdensome for the debtor, refusal to provide a countergrant despite the debtor's delay; the obligation to cooperate between the debtor and the creditor (obligation to cooperate), including the obligation to provide information; the duty to take care of the counterparty, including the obligation to ensure the safety of the counterparty and even the property of third parties; not to make a profit by violating the terms of the contract; the right to demand changes or termination of the contract in the event of a significant change in circumstances (clausula rebus sic stantibus) [3].

The concept of "good faith" is much more precisely defined by the term "good faith owner". This subject is a person who did not know and could not have known that the person from whom he or she acquired the property had no right to alienate it.

The increasing importance of the principle of good faith enables civil parties to protect themselves against actions that are not formally contrary to the law, but are in fact aimed at violating the interests of the counterparty [11].

Novitsky defines integrity as an external criterion, that is, in an objective sense, a minimum standard of social behaviour. Human behaviour should not fall below this line. So, bad faith is a violation of some minimum standard. But it is very difficult to define the boundaries of this standard [2].

The doctrine of good faith is recognised as a general principle of contract law. Generally speaking, good faith is a concept of honesty, which means not accepting evil (criminal revenge) or wanting to deceive others [6]. But good faith is a subjective concept and must be applied and applied separately to each situation.

In one of the largest institutions of civil law, the principle of good faith is also important in transactions. In order to determine the bona fides of the relationship between two persons, in each case the transaction must take into account acts and facts similar to the personal, cultural and economic status of the parties to the transaction. This means that the integrity standard cannot be applied automatically.

\section{Reflection of the principle of fairness in the current Civil Code of the Republic of Uzbekistan and in the} draft new Civil Code.

After 1991, the year of independence, Uzbekistan chose market economy based on free and fair competition [12]. The General Part of the Civil Code contains many provisions relating to the principle of good faith. Some articles explicitly refer to this principle. Some articles do not explicitly state to the contrary, but nevertheless, the rules themselves are a materialisation of the principle of fairness, a concretisation of it. The Civil Code currently in force is characterised by notions of good faith, decency, honesty, reliability and even fairness, which are embedded in the principle of justice.

Articles 5 and 9 promulgate and legitimise the principle of good faith in civil law through the general rules of the Civil Code. In particular, article 9 (3) of the Civil Code provides that the exercise of civil rights must not violate the rights and legally protected interests of others. Parties to civil law relations are expected to act honestly, rationally and fairly [7]. It is clear from the norm that the actions of participants in civil proceedings must be based on good faith, i.e. honesty. Article 5 of the Civil Code also attempts to clarify the subjective meaning of the principle of good faith in the norm. In particular, where semblance of law is not possible, the rights and obligations of the parties shall be determined in accordance with the general principles and content of civil law (semblance of law) and the requirements of good faith, reasonableness and fairness. That is, the requirements of good faith, reasonableness and fairness with regard to the subjects of relations affected by the likeness of law determine the specifics of behaviour of the subjects during the emergence and existence of these relations. "Good faith" means practical good faith in the conduct of the subject. [8]

Under Article 45(3) of the Code, a person acting on behalf of a legal entity in accordance with the Law or the constituent documents of the legal entity must act in good faith and reasonably in the interests of the legal entity he represents. It is established that, at the request of the founders (participants, shareholders) of the legal entity, he must compensate for the damage caused to the legal entity, unless otherwise provided by law or contract. That is, a person acting on behalf of a legal entity in accordance with the law or the constituent documents of the legal entity to be honest in the interests of the legal entity it represents, to achieve the objectives of the legal entity it represents, and to protect its interests with the standards in accordance with which it acts to achieve them. It can be inferred from this Article that a person acting on its behalf on the basis of the law or the constituent documents of a legal person shall necessarily act in good faith in its actions.

Adoption of a new Civil Code to further improve Uzbekistan's civil legislation, which will improve the existing principles of civil law, taking into account the moral principles and moral norms of society and international standards ("good faith", "fairness", "reasonableness", etc.) and the question of introducing new ones crossed out [12]. In the new draft Civil Code, the principle of good faith is expressed in words synonymous with 
honesty and decency, with particular emphasis on this. This principle, unlike in the current Civil Code, is reflected in the draft code, which regulates relatively more relationships and assesses the actions of civil parties. is mainly used to set certain limits on judicial discretion.

In particular, Article 11 of the draft of the new Civil Code, entitled "Exercise of Civil Rights", stipulates the honesty of participants in civil law relations and the reasonableness of their actions. However, the concept of honesty of participants in civil law relations is not defined in the current Code or in the draft Code. There is no limit to what the principle of good faith should consist of [15].

Under the new draft Code, the concept of "good faith" has been clarified in defining the term " conscientious possessor". In particular, Article 179 of the draft Code, entitled "Conscientious possessor", defines this concept as follows: conscientious possessor is a person who lawfully owns an object or is deemed to have lawful authority based on the scrutiny required in a business relationship.

That is, when assessing the bona fide owner's bona fides, his or her lawful possession of an object must be taken into account and it must be determined whether he or she has lawful authority in the business relationship, based on thorough checks.

Article 253 of the draft new code also defines a bona fide owner as a person who has paid, does not know and cannot know about the person who has the right to transfer the property to another person. An acquisition can be considered fair if the owner does not have (not know) reliable information about the illegality of the contract of alienation and the legality of the transaction is questioned by any reasonable person involved in a civil relationship under the terms of the contract. A situation in which it is clearly impossible (impossible to know) is common. The acquisition of property at a disproportionately low price on the basis of the transaction, as well as the fact that the transaction is conducted secretly from others, or that it is obvious that it does not belong to the alienator, etc., should be classified as dishonest.

The code also reflects the principle of good faith with the word "honesty" and the draft code states that contract terms that are contrary to the principle of honesty should be declared invalid.

\section{What are the objectives of the principle of good faith in civil relations?}

In order to better understand the content of the civil rules relating to the principle of good faith, it is important to consider them in the overall system of this principle through their functions.

An analysis of the intensive development of the principle of good faith in jurisprudence and doctrine, which has lasted for over a century, reveals a rather clear internal system of the principle of good faith. It is defined by specific legal functions (defining function, supplementary function, restraining function and corrective function), which are directly aimed at regulating social relations. The functional method of systematisation makes it possible to determine more precisely how the principle of good faith works in a particular legal relationship.

The analysis of more than a century of intensive development of the principle of good faith in judicial practice and doctrine allows us to identify a sufficiently clear internal system of the principle of good faith. It is disclosed through special legal functions (specification function, supplementary function, restrictive function and corrective function), which are aimed directly at regulating social relations. The functional way of systematisation allows for a clearer definition of how the principle of good faith can operate in certain legal relations.

Concretising function

The scope of this function is to regulate pre-existing, incurred rights and obligations. Exercising rights and performing duties must meet the criteria of good faith. It is the scope of the specifying function to determine how and in what manner the duties of a good-faith debtor are to be discharged. This is grounded in one of the basic rules of the principle of good faith, namely, the obligation of the parties to take into account the rights and interests of each other.

Complementary function

In this function, the principle of good faith is applied when it implies that the parties to a legal relationship have certain duties not explicitly stated in the terms of the contract or the rules of law. The relations of the parties within the existing legal relationship, as well as those that may arise or terminate, have a definite or determinable objective as regards the law and the totality of the parties' rights and interests. This goal cannot always be achieved solely through the fulfilment of the primary duties that comprise the subject matter of the obligation.

Restrictive function

If the exercise of a subjective right is formally consistent with the existing statutory framework, but at the same time contradicts the principle of good faith, it should be restricted. In such cases, the exercise of subjective rights must be restricted to the extent that it complies with the principle of good faith. The duty arising from the principle of good faith to take into account the rights and interests of the other party also provides a certain scope for legal regulation, including limitation of subjective rights.

Corrective function

Due to the change of circumstances in the existing legal relations, the performance of the obligation by the debtor may be limited, the obligation may be modified or the debtor may be relieved of the performance of the obligation altogether. A common basis for such modifications is the situation where performance of the obligation 
in principle or unchanged is unacceptable for the debtor. The concept of inadmissibility derives from the principle of good faith and is closely linked to the rule that the rights and interests of the other party must be taken into account. Inadmissibility may be based on personal subjective reasons of the debtor or due to a significant imbalance of interests of the parties due to unforeseeable changed circumstances.

\section{Conclusion}

The need to amend the current Civil Code to strengthen the principle of good faith is due to a number of objective reasons. First, the existing references in the Civil Code to good faith as a subjective criterion for assessing the conduct of civil law subjects and as an objective basis for regulating civil relations prove insufficient for effective legal regulation.

When considering the issue of the good faith of participants in civil legal relations, the courts refer to basic principles of civil law or private law, which do not mention the principle of good faith.

The absence of a clear principle of good faith in Uzbekistani civil law, as opposed to international private law, may affect fair decisions in the international courts in disputes involving Uzbekistani nationals.

Second, the principle of good faith is consistent with the views of contemporary civil law doctrines. This principle is enshrined in the legislation of most countries with a developed legal system and is clearly defined in the legislation of some CIS member states. In particular, Article 2 of the Civil Code of Belarus, along with other principles of civil law, states that the good faith and reasonableness of participants in civil legal relations [9], unless otherwise provided for, are based on the principle of fairness and reasonableness of participants in civil legal relations.

According to the current Civil code of Ukraine the general principles of civil law are:

1. The inadmissibility of arbitrary interference in the sphere of a person's private life;

2. Inadmissibility of deprivation of property rights, except in cases established by the Constitution of Ukraine and the law;

3. freedom of contract;

4. the freedom of entrepreneurial activity that is not prohibited by law;

5. judicial protection of civil rights and interests;

6. justice, good faith and reasonableness. [10]

A clear understanding of the content of the principle of good faith is crucial to legal practice. This is particularly evident in contract law: it is impossible to recognise a transaction as one conducted in bad faith or beyond the limits of one's authority without qualifying the actions of one of the parties as unfair and in some way prejudicial to the interests of the counterparty. Strengthening the importance of the principle of good faith allows participants of civil turnover to obtain protection from actions that do not formally contradict the requirements of the law, but are actually aimed at infringement of the counterparty's interests.

However, it is crucial to clearly define the boundaries of the concept of "good faith", as its unduly loose interpretation can lead to undesirable consequences, including the unjustified expansion of judicial discretion, which in some cases threatens the observance of the rule of law

Thus, we can conclude that the amendments made to the Civil Code are undoubtedly of principle and significance for the development of Uzbek civil law. [ The principle of good faith extends to the acts of civil parties in establishing rights and obligations, exercising rights and discharging obligations, and protecting rights.

\section{References}

1. Mackaay E., Leblanc V. The law and economics of good faith in the civil law of contract. - 2003.

2. Принцип добросовестности в обязательственном праве. Краткий теоретический обзор. Балло Никита

Александрович. https://zakon.ru/blog/2020/4/13/princip_dobrosovestnosti_v_obyazatelstvennom_prave_kratkij_teoreti cheskij_obzor

3. Принцип формального равенства и взаимное признание права. Коллективная. Монография под общей редакцией Доктора юридических наук, Профессора В. В. Лапаевой, Доктора юридических наук, Профессора А. В. Полякова, Кандидата юридических наук, доцента В. В. Денисенко. Москва. 2016 г.

4. Troy Keily, "Good Faith \& the Vienna Convention on Contracts for the International Sale of Goods (CISG)", in Vindobona Journal of International Commercial Law \& Arbitration, vol. 3, 1999, pp. 17-18

5. Mackaay E. Good faith in civil law systems: A legal-economic analysis //Revista chilena de derecho privado. - 2012. - №. 18. - C. 149-177.

6. Quagliato P. B. The duty to negotiate in good faith //International Journal of Law and Management. 2008.

7. Part 1 of the Civil Code of the Republic of Uzbekistan https://lex.uz/docs/111189 
8. Ўзбекистон Республикаси Фуқаролик кодексига шарх. 1-жилд (биринчи қисм) Адлия вазирлиги. - Т.: «Vektor-Press», 2010.- 816 б.-(Профессионал (малакали) шархлар).

9. Civil code of Belorussia https://xn----7sbakgchdukjdc8auvwj.xn--90ais/

10. Civil code of Ukraine https://meget.kiev.ua/kodeks/grazdanskiy-kodeks/glava-1/

11. Карпеченко М. М. Принцип добросовестности в современном гражданском праве //Молодой ученый. - 2014. - №. 20. - С. 477-479.

12. Ходжаев Б. К. Переходная модель конкуренции для регулирования вводящей в заблуждение рекламы в Узбекистане: альтернативный подход //review of law sciences. - 2020. - №. 4.

13. Рузиназаров Ш. Мажбуриятларни бажаришнинг таъминлаш усули сифатида мол-мулкни ушлаб қолишнинг цивилистик мохияти //юрист ахборотномаси. - 2020. - Т. 1. - №. 5. - С. 13-18.

14. Eylem Apaydin. The principle of good faith in contracts. Under the international uniform laws cisg, unidroit principles and principles of European Contract law. - 2019.

15. adjibayeva Mahsuda Rustamjonovna. Unfair competition by descrediting. //Review of law sciences. 2021. - №. 3. 